\title{
The shifted ownership regime of a common-pool resource: the case of water exploitation in Sanandaj County, Iran
}

\author{
Nishtman Karimi ${ }^{a}$, Kobe Boussauw ${ }^{\mathrm{a}}$ and Farzad Karimia \\ a Cosmopolis Centre for Urban Research, Department of Geography, Vrije Universiteit Brussel, Brussels, Belgium \\ b Vrije Universiteit Brussel, Brussels, Belgium
}

CITE AS: Karimi, N., Boussauw, K., \& Karimi, F. (2020). The shifted ownership regime of a common-pool resource: The case of water exploitation in Sanandaj County, Iran. Water International, 45(7-8), 765-787.

https://doi.org/10.1080/02508060.2020.1833134

ABSTRACT In this article, we reveal how a shift of water ownership regime has affected overexploitation of water resources in Sanandaj County, Iran, since the nationalization of water resources and centralization of the water policy in the 1960 s. The shift was subject to structural changes concerning monitoring, the size and type of user groups, and the actors involved, and we conclude that the state has unintentionally turned a communal ownership regime into a regime of open access to common-pool resources. The article adds to the knowledge on how a communal ownership regime could successfully sustain water as a common-pool resource.

KEYWORDS Water ownership regime; property rights; commonpool resources; folk water management; Iran

\section{Introduction}

In many places in the world, population growth and the consequent decline of available natural resources per capita have fuelled competition between resource users, which in turn has caused user demand to surpass systems' capacities (Barnett \& Morse, 2013; Feeny et al., 1990; Hardin, 1978). This entailed social issues which have not been adequately remedied, given the numerous deficiencies in the monitoring and control of user performance in such systems. The severity of such tensions is strongly related to the prevailing ownership regime of common resources and how these are managed by users (Clark, 1980; Ostrom et al., 2002). In many cases, problem-solving strategies and processes to precede actions have been developed, but these are highly context-dependent and rely on local communities' particular sets of basic assumptions, which are subject to change over time (Ostrom \& Hess, 2007; Pahl-Wostl et al., 2006).

To avoid a 'tragedy of the commons', as coined by Hardin (1968), several researchers (Agrawal, 2003; Cinner \& Aswani, 2007; Heynen \& Robbins, 2005; Sakurai et al., 2004; Tucker, 2010) have assessed the efficiency of having common resources managed by governments, communal groups, cooperatives, associations and individuals. Classical institutional analyses such as the one performed by Hardin assume that in order to sustain common resources in the long term, ownership regimes should be limited to private or governmental ownership (Dietz et al., 2003; Feeny et al., 1990). Similar views are expressed by Ervin (2003) and Lovejoy (2006), who recommended governmental ownership, while Clark (1980) and Raymond and Raymond (2003) suggested privatization as a solution to the problem of implementing operational rules and efficient individual rights of access and withdrawal of resources, stressing the need to establish well-defined property boundaries, and the assumed higher productivity of private regimes.

Alternatively, a growing body of literature (Cinner \& Aswani, 2007; Li et al., 2007; Tucker, 2010) proposed evidence of communal ownership regimes serving effective operation, based on the finding that local people have applied social mechanisms for the sustainable use of resources, which are rooted in traditional knowledge and local practices of resource management (Berkes et al., 2000; Ohmagari \& Berkes, 1997). Other authors (Clark, 1980; Sakurai et al., 2004) considered communal ownership regimes generally less efficient, due to limited rights to the exchange of ownership shares within the community. Furthermore, Ostrom and Hess (2007) assumed that physical systems (both natural and constructed storage facilities, such as dams) are as essential as social systems to the successful establishment of individual withdrawal rights to common resources. That is because such systems support accurate and low-cost monitoring, including obtaining information about extraction rates. 
A related strand of literature evaluates institutional reforms in water management, showing that reforms' outcomes differ in various contexts. In China, for instance, reforms of traditional water management structures for water security have failed to provide support for water conservation, and consequently created concerns regarding the social stability, economy and environment of several regions in China (Cai, 2008; Huang et al., 2009; Jie, 2011). In another case, in Lebanon, the national government has repeatedly passed bills to reorganize regional water authorities and allocate competences to the national Ministry of Water and Energy. Although the reform is still in its initial phase, institutional, administrative, technical and financial weaknesses have already become obvious (Comair, 2007). In a third case, in India, we see that the ability of the state to secure water allocation in some regions was facilitated by the institutional reforms (Punjabi \& Johnson, 2019).

In the current article, we examine the efficiency of private and state regimes for ownership water resources on the one hand, and on the other hand demonstrate how gaps in a regulatory framework can unintentionally create an open access regime with respect to the common-pool resource of water, which leads to collective-action dilemmas and potential tragedy-of-the-commons scenarios. We describe our propositions through a qualitative approach, identifying and analyzing institutions in use and the water management structure in Sanandaj County, Kurdistan Province, in the west of Iran, where, since the nationalization of natural resources in the 1960s, the local management of water resources has gradually become subject to the national water policies. We have chosen this specific case because of the highly interesting operation of two distinct management structures and the risk of future social conflict. We will show that private and government ownership regimes are not able to stabilize the exploitation of water resources in this case. Apparently, communal ownership aspects, neither attributed to the state nor falling under the notion of private ownership, had brought stability to the water resources as a 'common migratory resource' (Berkes, 2005; Feeny et al., 1990), which means that the number of resource units which could be extracted (e.g., a certain volume of water) is typically not predetermined within a resource system (e.g., an aquifer).

We proceed with a literature review, which will clarify the relationship between a multitude of property rights and various ownership regimes of a common-pool resource.

\section{Water as a common-pool resource: a typology of ownership regimes and property rights}

The large size of most common-pool resources allows them to be exploited by many users. As a consequence, the users face two difficulties: excludability, or control of access; and subtractability, or rivalry: each user is capable of alienating part of the resource so other users cannot benefit from it (Ostrom, 2002). Generally, communities of resource users have developed particular institutional arrangements, such as strategies, norms and rules, embodied in public policies or social conventions, by means of which they organize individual and collective behaviour to extract and manage common-pool resources and to facilitate the achievement of set goals and desired outcomes. Within governance settings, institutions may be formally codified into public policies, or may be represented by informal understandings, such as social norms (Siddiki et al., 2019). In this regard, common-property resources are a subgroup of common-pool resources, for which property rights were developed to deal with difficulties related to multi-user resource extraction about what actors are permitted, required or prohibited to do within temporal, spatial or procedural constraints (Feeny et al., 1990; Ostrom, 2008; Siddiki et al., 2019). According to Ostrom and Hess (2007), these rights represent 'an applicable authority to particular activities in specific domains that individuals can take actions in relation to other individuals'. However, the literature is not unambiguous when it comes to the types of property rights of common resources (Bromley, 1991). Five property rights are distinguished that need to be taken into account when assessing the governance of common-property resources: access, withdrawal, management, exclusion and alienation (Ostrom \& Schlager, 1996; Schlager \& Ostrom, 1992). 
Those individuals who have access and possess a withdrawal right are 'authorized users'. The holders of management and exclusion rights, which can be holders of both access and withdrawal rights in some communities, have the authority to create operational rules and user constraints, and can allow authorized users to transfer their rights to others (alienation), either temporarily or permanently (Ostrom, 2000). The application of the five types of property rights is affected by four general ownership regimes of common-pool resources, a distinction that depends on who holds the bundle of rights (Aligica et al., 2014; Feeny et al., 1990; Schlager \& Ostrom, 1992).

- Open access: the lack of well-defined property rights results in unlimited and free access to the resource by everyone, while no legal right allows exclusion of authorized users from using the resource, and no limits are imposed.

- Private ownership: the right, based on regulations and vested in an individual or group of individuals, to exclude others from harvesting the resource. This right is usually limited and exchangeable, which in much of the economics literature is considered equivalent to the right of alienation.

- Communal ownership: a shared ownership regime under which an identifiable community of interdependent users holds the resource and only the members of a community of interdependent users have the legal right to exclude nonmembers of that group from using the resource.

- State ownership: resources are exclusively assigned to the government, which makes decisions concerning access and withdrawal. In this context, Feeny et al. (1990) consider the category of state property as a public property to which equal access and rights apply, while in the case of private property, the state has the power of enforcement.

Changes in the management structure can lead to changes in the characteristics of the property rights or may blur the boundaries between the various ownership regimes, even if this was neither intended nor planned. These unintended changes of property rights can convert communal ownership regimes into open access regimes of common-pool resources. This means that, in the event of changes in institutional arrangement, users of a common-property resource might lose their property rights as it turns into an open access regime, whether it is owned by national, regional or local governments, or by communal groups or private users (Figure 1). Such unpredictable changes can happen due to failure to deal properly with two intrinsic difficulties of common-pool resources. The first is the inefficient excludability of users who display misconduct, due to insufficient monitoring of the use of large-scale resources, the high transaction costs of efforts to reduce negative externalities from overuse, inadequate sanctioning under less well-defined rules, and rule-breaking behaviour. The second is excessive rivalry, which is the risk of all users engaging in an unproductive race to capture as much of the resource as everyone else. Such open and uncontrolled exploitation by access holders brings congestion, over-harvesting, potential destruction of both ecosystems and social-economic constellations, opportunistic behaviour, and moral hazard problems on the part of whoever can gain access (Dietz et al., 2003). 


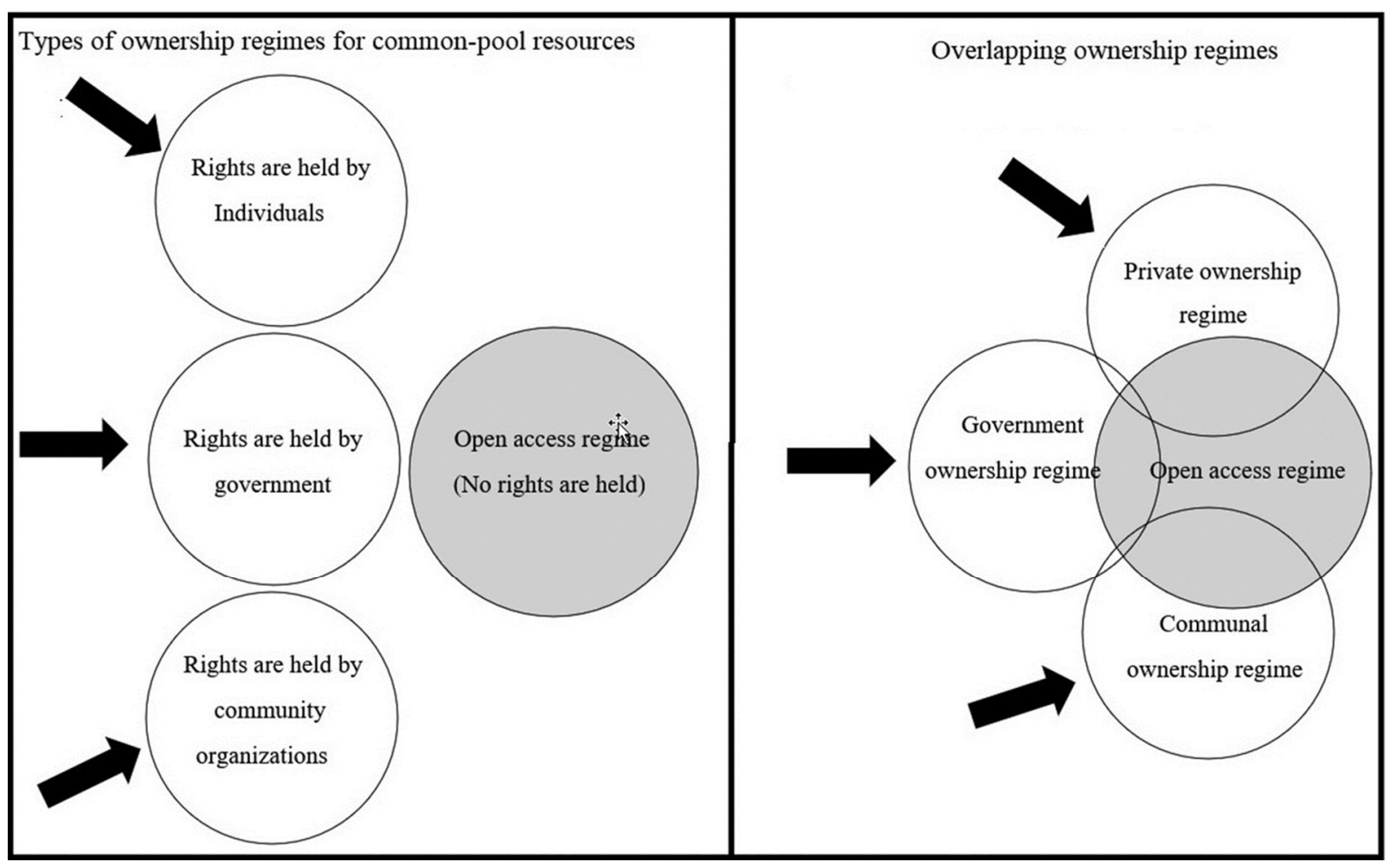

Figure 1. Changes in management structures alter the characteristics of property rights and as a result shift ownership regimes towards open access to common-pool resources.

It is therefore essential to consider that various types of common-pool resources exhibit different characteristics under different management structures or set-ups of ownership regimes, as well as eventually - applicable property rights (Ostrom \& Hess, 2007). For instance, some resources are stable, such as the pastureland that was used in the metaphor by Hardin, while some are migratory, such as volatile groundwater flows. The regulation of access to migratory resources is obviously different from access to stable resources, since upstream users can take away the fair share of downstream users through over-extraction of groundwater on their own land (Ostrom, 2000).

In the following section, we will provide evidence of how changes of ownership regime have been influencing the relationship between the state and communities of water resource users on the one hand, and the characteristics of property rights of water on the other hand, as well as the general sustainability of water resources in each of the two consecutive water management structure periods distinguished in the study area.

\section{Outline of the study area}

The county of Sanandaj includes Sanandaj City, which has 500,000 inhabitants and 195 villages in an expanse of 3,000 square kilometres in the Sirwan basin (Statistical Centre of Iran, 2016). While the regional yearly average of almost $500 \mathrm{~mm}$ of rainfall is unequally distributed across space and time, it is twice the country's average. Most of the country's area, particularly the eastern and southern parts, receives no more than $200 \mathrm{~mm}$ of annual rainfall, and more than $75 \%$ faces levels below $300 \mathrm{~mm}$. Only $8 \%$ of the country, mostly in the northern and western parts, receives more than $500 \mathrm{~mm}$. Most the country is classified as semi-arid or arid (Madani, 2014). Also, a combination of droughts caused by climate change (Tabari et al., 2011) and a demographic boom have reduced the available water resources per capita from about 5500 cubic metres in 1961 to 1718 cubic metres in 2011, so a large part of Iran, home to 37 million people, is exposed to severe water stress (Energy Ministry, 2015). 
Although the natural water supply in the study area is generally sufficient, parts of the rural area have regularly faced severe water shortages in recent decades, which suggests a mismatch between water availability and distribution. Only a few studies (Balali, 2009; Foltz, 2002; Madani \& Dinar, 2010; Madani, 2014; Moqimi et al., 2016) have investigated the roots of this mismatch at the national level to any extent. Our own analysis will therefore add to the knowledge of the effect of regional and national water management structures at a county level, paying particular attention to the influence of changes in the ownership regime and how property rights to water resources are dealt with. This will highlight one of the roots of the current issue of water scarcity in Iran and the various social dilemmas that need to be overcome for water sustainability.

We apply a qualitative approach to the history and dynamics of the water ownership regime and the issue of water overexploitation in the study area during two distinct periods of planning. The first period comprises the 'folk co-management' structure, which is characterized by the joint management of water resources under communal ownership, with governance based on rules locally crafted and socially enforced by the local users themselves (Berkes et al., 2000). This era ended in the 1960s, when the Iranian government initiated the nationalization of water ownership (Madani \& Dinar, 2010; Moqimi et al., 2016). In the second period, the state gradually imposed a technocratic management approach for all of Iran. The current state-led water management is characterized by the presence of a multiplicity of interests, and there are multiple government administrations in play (Madani, 2014). Distinctions between the two eras are manifest when it comes to both 'soft measures', such as regulations, institutions, taxation and monitoring, and 'hard measures', such as the construction of technical infrastructure, planning interventions, or engineering practices (Dietz et al., 2003; Pahl- Wostl et al., 2006).

Evidence of the 'folk' water co-management structure that we discuss here originates from a combination of interviews in 2015 with 10 elderly residents of the villages of Dushan, Hasanabad and Navarah in Sanandaj County (Figure 2), all of whom are former members of local water associations in their villages, and a review of relevant literature and historical official documents. The traditional folk comanagement in these villages is still partially functioning based on a few remaining qanat systems, which are man-made underground tunnels for water storage and distribution (Wulff, 1968). Evidence of the current water management structure was obtained from a focus group survey with 15 local experts in the fields of water resource management, regional planning and water engineering, and personal interviews with 14 inhabitants of five other villages under scrutiny (Degairan, Zunj, Derila, Negel and Bezlana) in 2017 (Figure 2). Before nationalization, the water management structure was relatively similar across the eight villages featured in our study. However, this situation changed when some of them were confronted with severe water shortage (Derila, Negel, Navarah), while others (Degairan, Dushan, Hasanabad) apparently benefited from the increasing availability of water due to their vicinity to Sanandaj City. Additionally, one of the villages (Bezlana) and parts of the farmland of Zunj have been evacuated to make way for the construction of a reservoir (Table 1). 


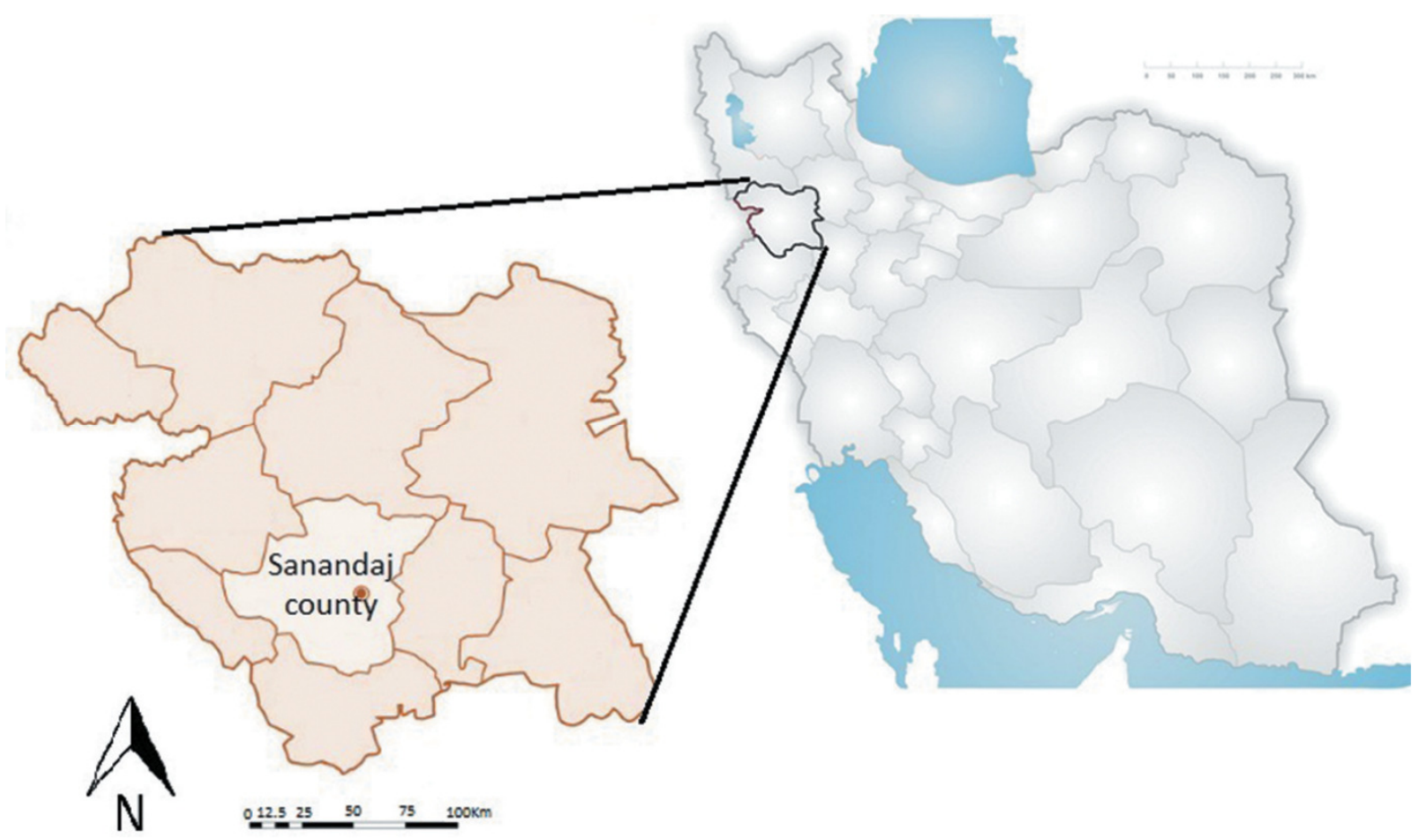

Figure 2. Location of the study area in Iran, including the villages under scrutiny. Source: 'Sanandaj', $35^{\circ} 9^{\prime} 43.19^{\prime \prime} \mathrm{N}$, $46^{\circ} 1^{\prime} 37.72^{\prime \prime}$ E, elev. $5611 \mathrm{ft}$., Google Earth, 3 December 2017.

In the focus group, three open questions were discussed consecutively:

(1) Which actors have been involved in water resource management of the study area since 1960 ?

(2) Which specific water management actions have been taken in the water system of the study area since 1960 ?

(3) What are the roles of and relationships between the actors involved, with respect to the implementation of each action?

This class of data was augmented by participatory observations in the public administrations of the Kurdistan Regional Water Authority and the Natural Resource Administration of Sanandaj County, while we provided consultancy for the local regional- environmental plans of these administrations. This position provided an opportunity to interact with administrators and to collect relevant in-depth data. More information was obtained from a review of official documents and grey literature, such as the existing laws and bills, the plans for the development and improvement of the agricultural land status, the provision of drinking water and water for manufacturing, and the development and improvement of agricultural lands, and reports of the Qeshlaq and Azad dam construction projects and historical resources.

This article should be viewed as an extended case study, which is representative of the implications of the undiversified national top-down policy of the Iranian state and the impact of the shift in the natural resource ownership regime in the whole country.

\section{Past and current water management structures in Sanandaj County}

\section{Folk water management structure of the past: water resources under a communal ownership regime}

For many centuries, the local community of the central arid plain of Iran has developed traditional ecological knowledge about how to manage scarce water resources, through interpretation of ecological signals for learning and adapting (Berkes et al., 2000). This knowledge was manifested in the construction 
of elements of technical infrastructure, the qanats. Qanats were hand-dug underground tunnels developed to store runoff water and to gravitationally redirect groundwater over long distances and to the surface (Ahmadi et al., 2010; Amin et al., 1983). The system supported both irrigation and domestic use of water in rural and urban areas during dry seasons by storing and minimizing evaporation during transportation. The water supply was relatively stable since only annual surplus groundwater was discharged from aquifers (Boustani, 2008; Kordovani, 2015; Madani, 2014). An essential component of the knowledge and practices was a particular worldview or 'cosmovision' that considered the folk as a part of the ecosystem, which created the cultural values and the basic norms and rules in each community (Berkes et al., 2000) (Figures 3 and 4).

Table 1. Overview of number of respondents in both modes of data collection.

\begin{tabular}{|c|c|c|c|c|c|}
\hline \multirow{2}{*}{$\begin{array}{l}\text { Category of } \\
\text { respondents }\end{array}$} & \multicolumn{2}{|r|}{ Folk water management } & \multicolumn{3}{|c|}{ Current water management } \\
\hline & & Interviews & & Interviews & Focus group \\
\hline Government officials & - & - & - & - & 5 \\
\hline Academics or scientists & - & - & - & - & 2 \\
\hline Local residents & 10 & $\begin{array}{c}\text { From the villages of Navarah, } \\
\text { Hasanabad and Dushan }\end{array}$ & $\begin{array}{l}10 \\
14\end{array}$ & $\begin{array}{l}\text { From the villages of Navarah, } \\
\text { Hasanabad and Dushan } \\
\text { From the villages of Derila, } \\
\text { Negel, Zunj, Degairan and } \\
\text { Bezlana }\end{array}$ & 3 \\
\hline NGO officials & - & - & - & - & 5 \\
\hline Total & 10 & - & 24 & - & 15 \\
\hline
\end{tabular}

This system was therefore based on a decent basic knowledge of how to deal with the natural environment in an adaptive and sustainable way (Jomehpour, 2009; Wulff, 1968), which developed through many successes and failures of human-environment interactions, long-lasting observations of the local environment, and a practical understanding of physical mechanisms that was transmitted to future generations by shared practical experiences (Berkes et al., 2008; Ohmagari \& Berkes, 1997). This knowledge dispersed across the majority of local communities of the Middle East and beyond, which were dealing with periodic water scarcity (Madani, 2014). Eventually, based on mechanisms of cultural internalization, a locally adapted version of the knowledge of the water system informed the cultural values and basic norms and rules in each community (Berkes et al., 2000). These institutions are shared by each community, and are part of an oral tradition (Siddiki et al., 2019).

For a better understanding of the local version of the folk co-management structure and to investigate the nature of the process of transmission of knowledge in the study area, we selected the three villages of Dushan, Navareh and Hasanabad. In these three villages the remaining qanat infrastructure elements are still functioning. In most of the only 15 remaining villages of the county where qanats are still operating, water is available for only a few months a year and only to a limited number of users. Typically, in the central plain of Iran, the length of the qanat infrastructure ranged from a few hundred metres to 120 kilometres (Ahmadi et al., 2010; Wulff, 1968). However, the qanats in the study area were only a few hundred metres in length, due to the hilly physiography of the region. 


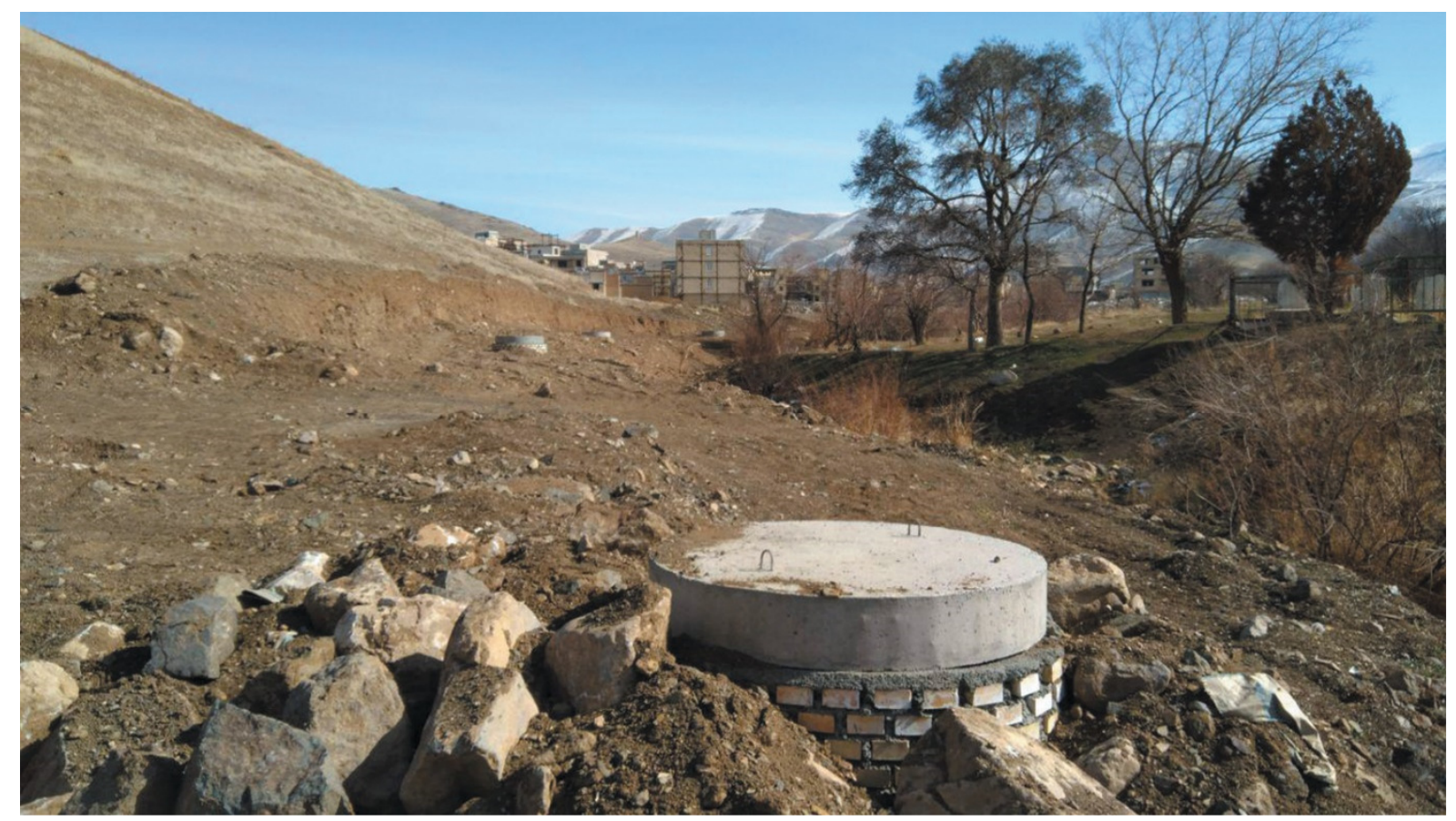

Figure 3. A hand-dug well in a hillside in the village of Dushan, for injecting runoff water into the qanat. Source: authors.

With respect to the collection of data on the dynamics of management structures, two difficulties were encountered. First, due to the area being near the border, detailed quantitative and qualitative data about the water resources, including the qanats, are considered confidential by the Iraqi government and are therefore were not available. Second, in the villages, few people with direct experience of the old water management structures were still alive and willing to participate in an interview. Consequently, a total of 10 interviews were conducted with people who had knowledge of the old system, and these concentrated on how the technical system was operated, how norms and rules were applied in the associations, and how the remaining qanats in the villages are currently managed.

A first finding is that the management structure of the qanats shares many characteristics with the institutional arrangements for the distribution of water from natural springs among users not served by qanats, except when it comes to maintenance and development of the infrastructure. A second finding, based on the statements by the interviewees and historical documents such as initial laws and literature, was that three layers of community-based rules could be distinguished, arranged in an informal hierarchy: constitutional rules, collective-choice rules and operational rules (Williamson, 2000). 


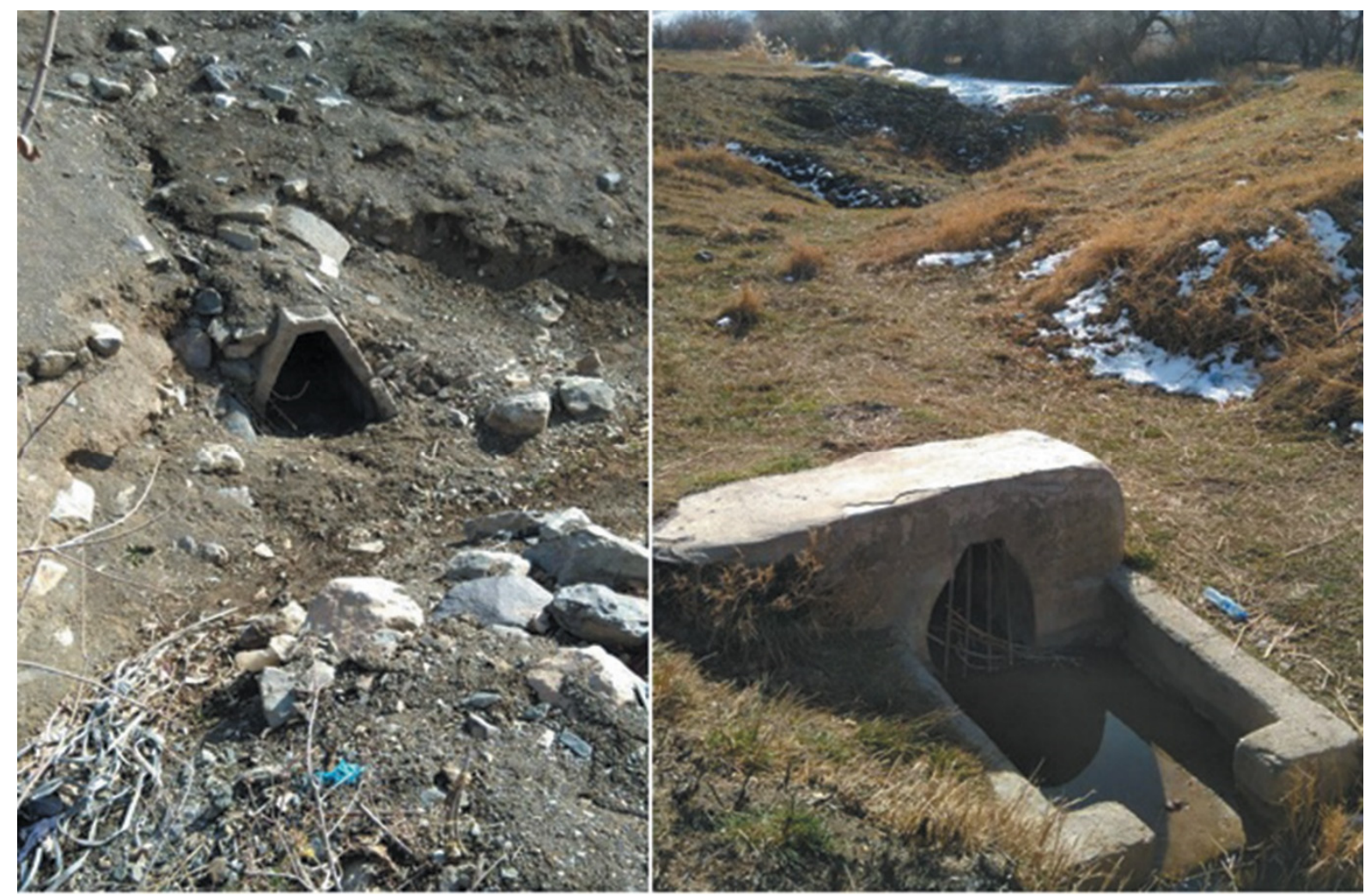

Figure 4. Left: An abandoned qanat in the village of Dushan. Right: A hand-dug tunnel for redirecting groundwater streams to the surface using gravity. Source: authors.

Constitutional rules regulate the ownership regime and its overall settings of governance, which determine the property rights of water users. The main constitutional rule in the county might be referred to as the National Civil Rights Law, which formally recognizes water as a type of economic good among the community of water users holding the resource. Based on the constitutional rules, a full property right, including the right of alienation, allowed authorized users to trade access and withdrawal rights either temporarily or permanently in exchange for other goods or money, so that anybody who purchased such rights was able to use water more efficiently. This manner of distribution of water resources strongly determined economic activities.

The constitutional rule created an umbrella under which collective-choice rules could be constructed, which resulted in the establishment of local associations which dealt with the use of water resources. The scope of these associations was in line with the local sphere of the villages, which depended on the availability of water from the springs and qanats, and on the workforce required to maintain the qanats. Usually, longer qanats or springs with a higher discharge were split into smaller management units. Currently, in each of the villages under scrutiny, a local water association is active, a collaboration between a few private owners. However, the interviewees stated that in the past, each water management association in the villages consisted of five to 15 water users on average, and included both farmers and other residents (Figure 5). The land in each village was owned by an individual main landowner, who supported the legitimacy of the associations with respect to his territory. No decisions were made individually; the members of the associations applied collective-choice rules through regular informal meetings and exchanged face-to-face information about the system conditions, monitoring, extraction and distribution, and the maintenance of the physical qanat infrastructure and springs, with respect to the current crop year. The collective-choice rules were buffered from external forces, and the state had no authority on the management of the water resource systems. Eventually, through the informal meetings, which were repeated annually, the members adjusted their decisions and practices based on environmental events at a local level. Also, the knowledge was transmitted to future 
generations by continuously replacing elders with younger members, so that learning could be encoded and retained by the members, a process generally known as intergenerational knowledge transmission (Berkes et al., 2000; Gadgil et al., 1993; Ohmagari \& Berkes, 1997).

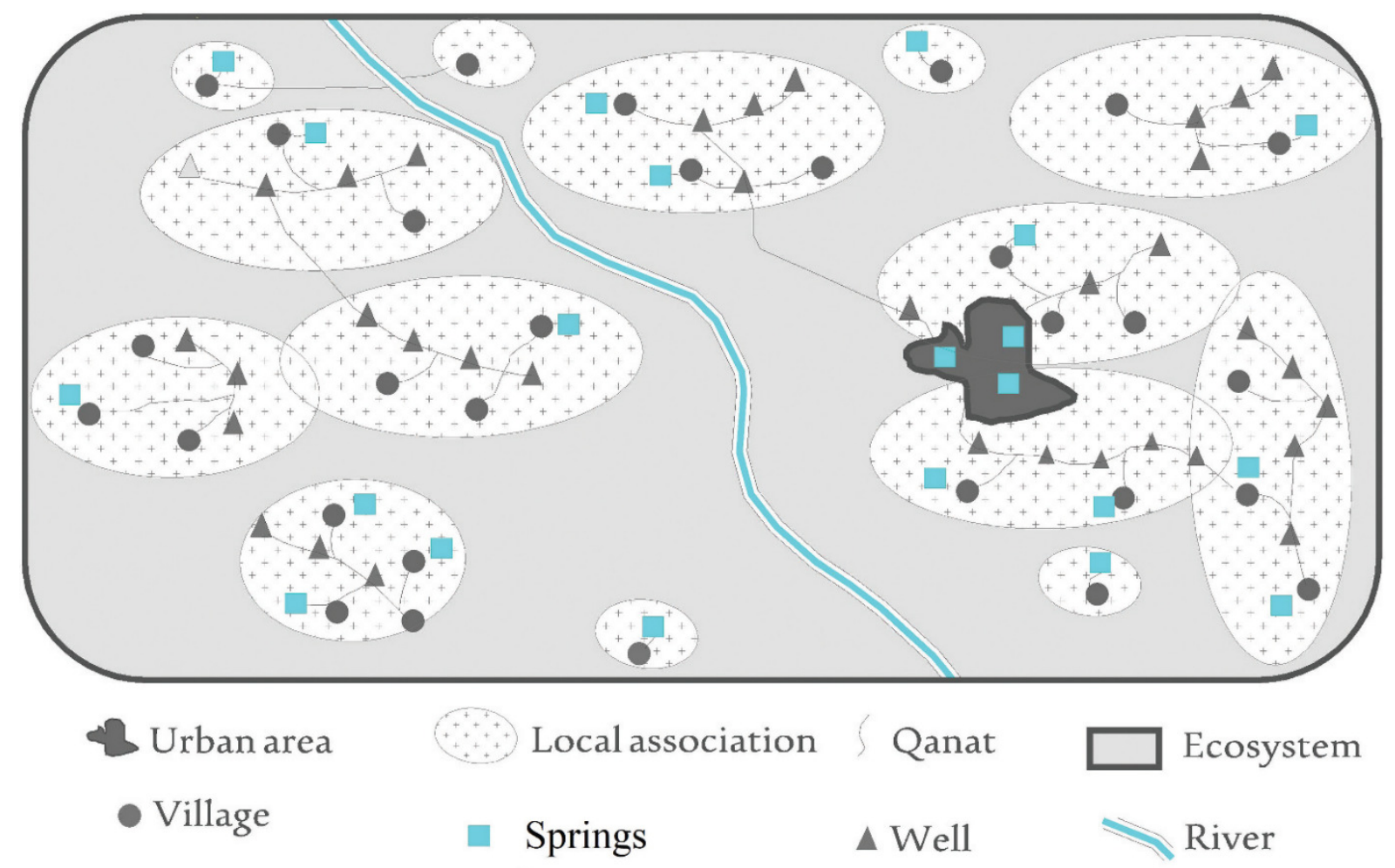

Figure 5. Sketch of the earlier 'folk' water management structure in Iran, based on communal ownership of surface and underground water. Source: authors.

Finally, the operational rules of the local associations allowed users to practice collective choice over the construction and maintenance of facilities, cooperate with other associations in the vicinity, negotiate the required input of labour, and devise limits on withdrawal rights by monitoring and sanctioning water users. The combination of operational rules created nested institutional arrangements of values and norms.

Interviewees stated that water allocation in each village was based on a 'water circulating plan', which determined the length of time between turns of being allowed to get water from the qanat or spring. In each association, this timing was based on the demand for water and the available flow. The implementation of the operational rules and monitoring activities was conducted by the leadership of an individual authority or local steward known as a sarabyar (water assistant) (Balali, 2009), who was authorized by the local ruler and the members of the association. Although there are currently no sarabyars left to enforce any rules, a handful of local inhabitants collaborate to manage and maintain the system. In the past, however, all members of the local association were required to share accurate information about the conditions of the resource and had to contribute a fair share of the work. In this way, both the responsibilities for and the benefits of the water resource were shared among all members. The collective decision making in nested communal co-management units reduced transaction costs with respect to the exclusion of non-authorized users from accessing the resource, as well as to monitor extraction and maintain the sanctioning scheme of the local stewards and the users.

However, the power relations in the management structure could be viewed as horizontal continua which depended on social hierarchy positions in the traditional community of each village. The interviewees also stressed a number of issues associated with this structure, including its strong hierarchical structure and not entirely equal distribution of labour and water among users of different 
social status. Although the folk co-management structure was not based on a scientifically developed ecological body of knowledge, it shows some similarities with adaptive management structures, since it evolved towards a continuous process of problem solving, rather than towards a fixedstate solution, to deal with the uncertain environmental conditions and substantial biophysical constraints on to the optimal use of water. The management structure was therefore able to respond adequately to issues of the local scale and environment (Dietz et al., 2003; Madani \& Dinar, 2010), while pursuing an equilibrium and having the capacity to absorb drought stress. In this way, its users managed to avoid the pitfall of water scarcity.

Based on our findings, it is clear that the collective decision-making scheme required users to engage in face-to-face communication to undertake common actions and share 11 experiences, which coordinated the organizational skills and knowledge of the members. In all the villages under scrutiny, this was based on useful, trustworthy information on decisions about and conditions of the resource systems. In this way, the folk associations of co-management effectively formed the basis of social cohesion, mutual trust, social norms and joint learning about water resource management at the local level.

In summary, the characteristics of local social-ecological interaction in the subsistence society of the villages seem to have provided appropriate conditions for effective selfgovernance of water resources, which in the end turned the practice of water management into a successful example of long-term sustainability of water resource use and guaranteed a considerable degree of stability of water resources while facing a dilemma of joint use of water and water scarcity in the long term. However, since 1962 the government has put legislation in place under the policy umbrella of land reforms, and nationalized the water resources. Consequently, decision making shifted from a traditional cooperative system to a new form of centralized control. This transformation ended the legitimacy of the folk co-management of water resources.

\section{The current centrally planned water management structure: water as a commonpool resource}

Increasing anthropogenic activities, including population growth, consumption, and advanced technologies for resource deployment, have changed the way communities organize themselves to extract natural resources (Dietz et al., 2003). The process of change of the Sanandaj County water management structure coincided mainly with the start of state centralization of water policy in the 1960s, which was called the White Revolution. This 'revolution' consisted of fundamental land reforms aimed at supporting private ownership of land, state ownership of natural resources, and industrialization of traditional economic activities (Pahlavi Dynasty). In this process, the government took over all authority for the access, withdrawal, management, exclusion and alienation of all water resources at the national level, since water resources were seen as a powerful tool for the state to control and balance regional development and national security (Karimi \& Boussauw, 2018; Madani, 2014) and the folk co-management structure was considered problematic with respect to the development and modernization of the country.

To understand the current situation of the water resources and how these are managed, we conducted participatory observations in the mentioned public administrations, organized a focus group with 15 members of the public administrations, and interviewed 14 inhabitants of the villages. Based on our analysis, we would argue that the state's physical intervention in the water resources management of the area began in 1974 with the construction of the Qeshlaq Dam, which is $20 \mathrm{~km}$ north of Sanandaj City, to modernize the infrastructure for urban water provision. In that era, the modern state of Iran introduced an institutional arrangement in the form of a top-down nested hierarchical model, which is mandated for all stages, ranging from formulation of policy down to implementation in Sanandaj County, including the villages of our study area. The highest level of the Iranian strategic planning system is the National Development Plan, which is prepared by the Cabinet and the National Parliament every four years. The 'Water and Sanitation Programmes' chapter of the National Development Plan is interpreted as a 
National Operational Plan by the Ministry of Energy, which results in the 12 creation of institutions for all the water resources. In the next stages the National Operational Plan is translated into local plans, through the interorganizational hierarchy, from the ministry level down to the regional water authority at the county level. In the end, the state administrators are the primary actors in this operation, initiating the creation of institutions in Sanandaj County.

In brief, the current institutional arrangement has three levels of actors: the decision makers, an executive level, and water users. Most decisions are made at the macro level within a multilayer legislative structure which is composed of constitutional rules, ministerial regulations and provincial regulations. The executive level has a limited number of layers of public administration, including the Regional Water Authority of Sanandaj, the Urban Water and Sewerage Administration, the Rural Water and Sewerage Administration, Sanandaj Municipality, the Natural Resource Administration of Sanandaj County, and the Agricultural Administration of Sanandaj, which cover the entire realm of water management, enable decisions and regulate the provision of water resources for the users. Each administration has its own territorial hierarchy, ranging from national to county level, inside the energy and agriculture ministries, which has obviously entailed an increase in the number of formal actors, levels and interests (Madani, 2014). The government officials in the focus group stated that since the period of reform, a number of public administrations dealing with water affairs have been split and consolidated again on several occasions, which has regularly caused confusion concerning the authority and competence of the various administrations and regulations. Similarly, differences in power and values between public authorities have created new and ongoing conflicts over environmental decision making, with adverse effects (described later in the article) on the water sector as a whole.

Ultimately, all legal rights in the water resource system in Sanandaj County, including the villages in our study area, are now attributed to the nested governance structure of the state, which is affected by political conditions. Only influential actors such as members of parliament and public administrations are involved; the involvement of local users has become limited to complying with the decisions made, at low levels of interaction and deliberation. The sphere of interactions has been transformed from the simple exchange of information at a local level to a formal partnership of public actors at a higher level, something typical of complex bureaucratic constellations.

\section{The impact on surface water}

As we have mentioned, the unbalanced distribution of population and industry in the cities in the central arid region exacerbated the mismatch between water delivery capacity and regional water demand in most parts of Iran (Larijani, 2005; Madani, 2014). Also, international trade sanctions encouraged the government to promote self-sufficiency in food/energy security and agricultural production in general (Marjanizadeh et al., 2010), which led to the development of new farmland on rangeland in the arid and semi-arid areas in our study area and other parts of Iran. Overall, the combination of the issues mentioned has turned water security into a national concern (Madani, 2014; National Central Bank, 2014), and it tends to strengthen the position of the state as a legitimate actor, allowing it to take more leadership in the business of providing and supplying water. For that reason, in 1983, the government passed a bill allowing it to take the lead in 13 a more balanced distribution of water, which was a turning point in surface water resource management, according to one statement in our focus group.

Based on the focus group findings, a new wave of physical construction works was initiated, mainly aimed at controlling upstream runoff behind dam reservoirs, to increase the predictability of yields, meet fluctuations in water demand, and divert water from drainage basins with sufficient water (one of which is home to our study area, where annual precipitation is twice the national average) to drier drainage basins or growing cities. The struggle for water diversion is strongly influenced by Iranian national policy dynamics and political conflicts between provinces. Again according to a statement from the focus group, the multiple layers within the public administrations and the power differentials within user groups have 
allowed some actors to ignore the original rules of common use, or to reshape them according to their own interests, while ignoring the obvious necessity for a careful social-ecological assessment of the possible local impact of each project.

The most powerful parliamentarians or governors largely represent the neighbouring provinces, especially Kermanshah in the south and Hamadan in the south-east. Based on our participatory observation in the public administrations and the statements of the focus group, these powerful actors are trying to respond to the demands of their regions of origin by passing bills in parliament to allow the construction of several dams in Kurdistan Province and our chosen county, to divert water and energy from Kurdistan Province to their own electoral area. Several dams have already been built in the motherland of the qanats, springs and villages. The county's local decision makers have also supported the construction of the Azad Dam, $40 \mathrm{~km}$ west of Sanandaj City, to meet the growing demand for water in Sanandaj City, in which 83\% of the inhabitants of Sanandaj County live (Statistical Centre of Iran, 2016). Although the traditional qanats and springs would not be able to meet this dramatic rise in demand, a staff member of Sanandaj's municipal administration stated that there are still 10 qanats present, albeit abandoned and covered by the urban fabric, which means that their water flows are dumped into the city's sewerage system without serving any practical use, while neither the municipality nor any other public administration has any information regarding these urban qanats.

As a result, the boundaries of the geographical area of water management no longer coincide with the delineation of the sub-basins of the Sirwan basin but rather with the provincial boundaries of Kurdistan (Figure 6). Also, according to the focus group and as shown by the list of current project contractors of the Kurdistan Regional Water Authority, the construction and engineering branch of the Iranian army performed an important part of the civil works involved in barrier construction. Clearly, this semipublic sector has been one of the most influential actors in the governance of water resources in Iran and in the county, up to the present day.

Nevertheless, some areas in the vicinity of the city of Sanandaj, such as the villages of Hasanabad and Dushan, receive more water than their renewable water resources can supply, and are therefore experiencing rapid urbanization and agricultural growth. Based on our observations in the villages and on our interviews with the inhabitants, the ecosystems and habitats in the source drainage basin, which includes the villages of Negel and Derila (Figure 7), are under threat from human-caused drought and water shortages, while the farmlands and built-up parts of several villages, including Zunj and Bezlana, have been submerged by reservoirs, which has directly or indirectly forced the 14 migration of some rural inhabitants to the cities in the vicinity, mainly Sanandaj (Karimi \& Boussauw, 2018). This increases the loss of water through evaporation of surface water in the reservoirs, the rate of which is already three times higher in Iran than the global average (Boustani, 2008). 


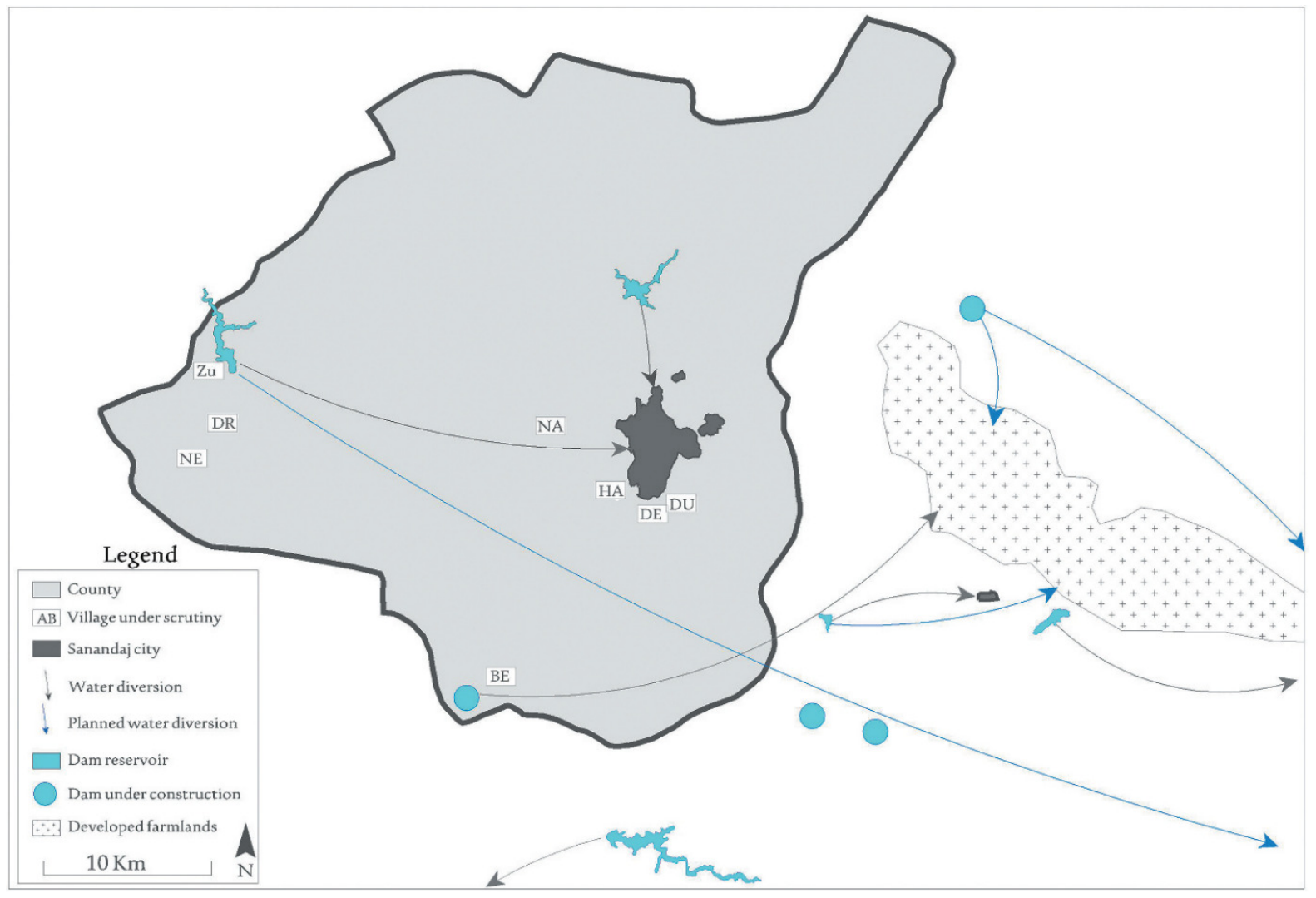

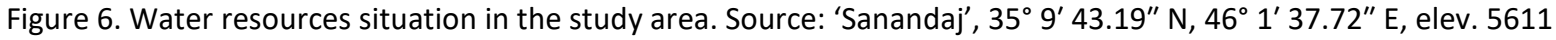
ft., Google Earth, 3 December 2017.

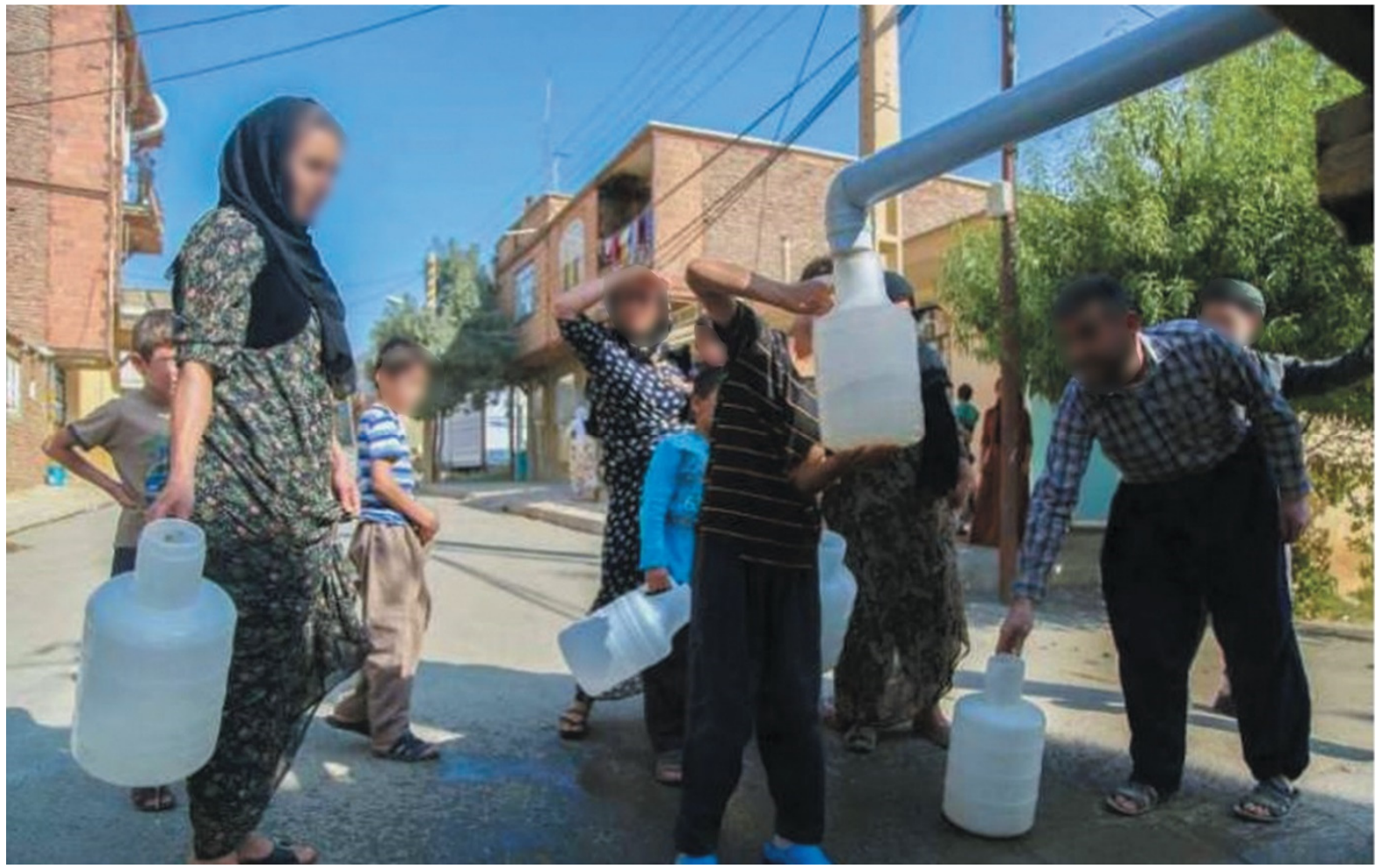

Figure 7. Provision of potable water to Hosseinabad Village, downstream of the Qeshlaq Dam, by tankers from the Rural Water and Sewage Administration of Sanandaj County. 
According to statements by the focus group and inhabitants of the study villages, it has become clear that in recent decades the water supply and the hydrological cycles of the basin, rivers and lakes have faced catastrophic degradation in both quantity and quality, while policy makers prioritize quantity over quality, being concerned about the use and diversion of water rather than pollution (Flaherty et al., 2011). Also, from the perspective of environmental justice and equitable distribution of opportunity, water distribution has become a matter of fundamental concern since it fails to include social justice as a part of socio-environmental sustainability.

\section{The impact on groundwater}

Based on 2018 data from the Kurdistan Regional Water Authority department, the pace with which authorized and unauthorized wells are drilled has dramatically increased in the study area in the last three decades, for several reasons. First, according to members of the focus group, while the former members of the water associations fostered intergenerational knowledge transfer, the current water users have lost their commitment to sustaining groundwater flows and are more interested in immediate benefits and economic incentives. Additionally, under the new legislation there is a clear gap in the regulatory framework for groundwater regarding regulation of access, withdrawal, and excludability on private lands. Surface water has clearly attracted more policy and research attention than groundwater resources, which weakened groundwater protection in the domestic legal system (Flaherty et al., 2011). The state allocates insufficient funding for the monitoring of private users; it only covers large-scale and remote monitoring practices by public administrations at the county level, consisting of the city of Sanandaj and 195 villages. Only 3\% of the water resource budget of the Energy Ministry, which is the legitimate authority, is allocated to groundwater, and $97 \%$ to the governance of surface water, which has mainly meant dam construction (Papeli Yazdi, 2016). Therefore, in the absence of both local monitoring and strong leadership in the local public administrations, water users have become quasi-autonomous in setting rules for their individual planning unit, which is usually their private plot of land.

Second, from the focus group and from eight inhabitants of Drela and Negel, downstream of the Azad Reservoir, we found that the dams and interbasin water diversion contributed to the drying-out of the downstream area. Farmers found themselves having to try to devise ways of evading governance rules in their individual planning unit, since the new top-down rules and supply-oriented strategies were not considered efficient or fair by most users. Part of the user community therefore started to extract more groundwater than before, through illegal wells (Figure 8). One Sanandaj municipal staff member we interviewed declared that this additional extraction should be added to the longstanding household water consumption of most villages under scrutiny and the partly unauthorized dwellings in the suburbs of Sanandaj City, which are also relying on groundwater, despite the nearby dams.

Third, regional decision makers tend to develop agricultural lands in line with the state goal of national self-sufficiency of crops. To meet this goal, national authorities have passed bills to support large-scale extraction and to legalize unauthorized wells. 16 Consequently cultivation patterns have changed, with a larger share of water-intensive crops in several parts of the study area and in other basins that depend on long-distance water supply, where inefficient productivity and fragmentation of land parcels has become prevalent. However, only $15 \%$ of the country's surface is cultivated, and despite consuming $92 \%$ of the water resources (of which only $30 \%$ adds to productivity), the agricultural sector accounts for only $10 \%$ of the country's GDP (Habibi, 2017; Madani, 2014). According to a statement in our focus group, these conditions have affected social learning processes and commitments to sustaining water supply, both in the study area and nationally. And jurisdiction seems rather flexible, since many unauthorized wells were legalized after the fact. Also, the state provides loans and financial support to the farmers in periods of drought, which negates any incentives for developing an ecological knowledge base that would allow adaptation to the unpredictable climate. 
At a later stage, when aquifer conditions had largely declined and most springs and qanats had dried out on a large scale, the state attempted to control the drilling of wells and rationed extraction by top-down strategies at the county level. But water users have developed a considerable capacity for inventing ways of circumventing the rules, such as drilling unauthorized wells, which undermines efforts by the countylevel administrations. Because resource users were once allocated individual extraction rights, efforts by the state to regulate extraction on a small scale are difficult and expensive. As a result, low compliance and strong resistance to the reinforcement of existing restrictions are inevitable, and the process of drilling and consumption has exceeded monitoring capacity.

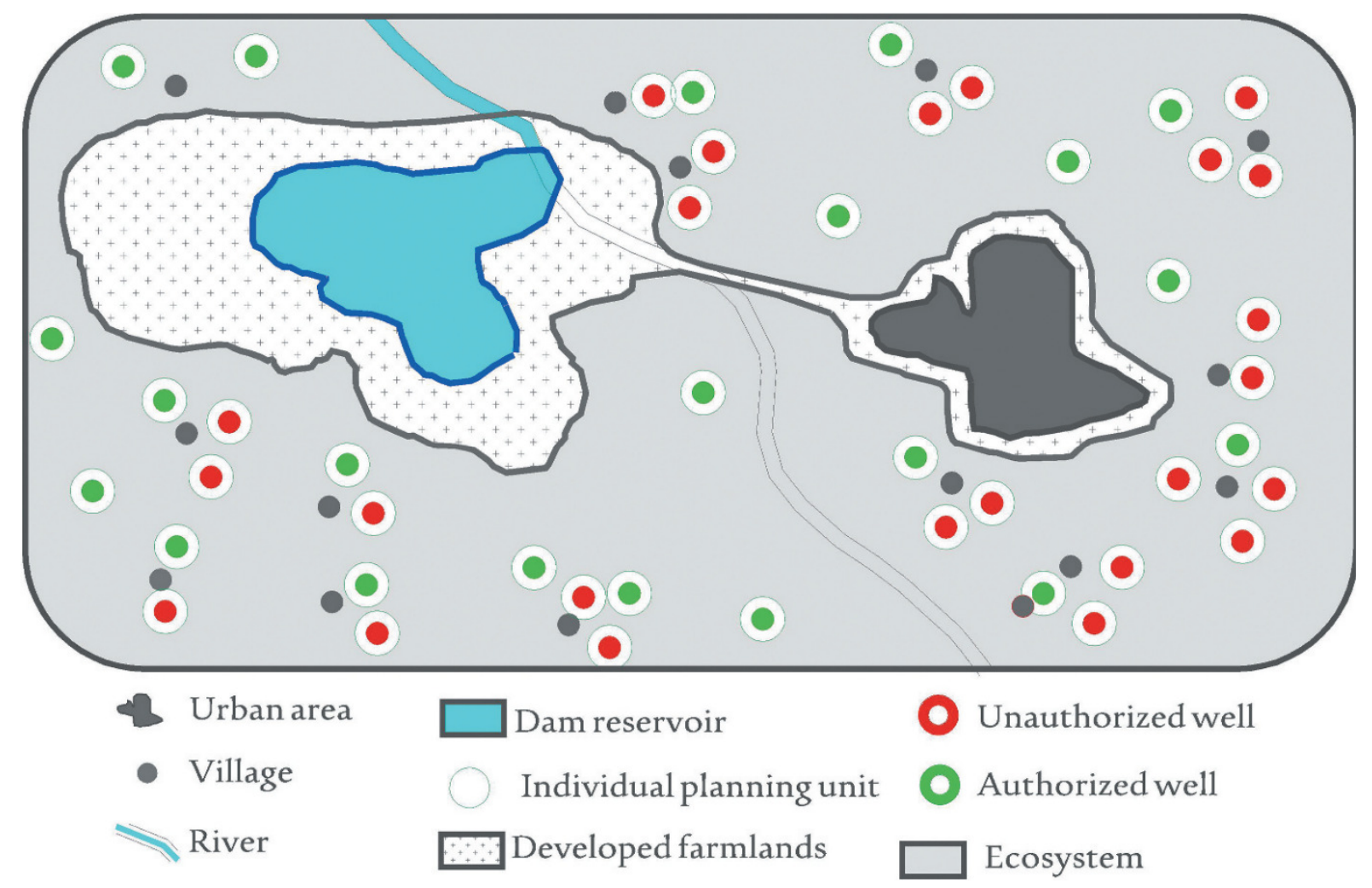

Figure 8. Sketch of the current water management structure in Iran, in which underground water is considered private property while stored surface water is considered state property. Source: authors.

\section{Consequences of the regime change: a discussion}

The informal structures for governance of natural resources in the traditional community of the study area originated from a long history of trial and error in the search for ways of adapting to the semi-arid climate and the unfavourable distribution of rainfall. The adaptations were built on the principle of communal ownership of water resources and based on a nested system of folk co-management rather than on a political-administrative hierarchy. The water users in the local associations exercised all their legal rights related to the resource system within the boundaries of the villages.

Following the centralization of state policy and nationalization of water ownership, the state, as the only decision-making authority, developed a nested structure of public administrations in the county to hold all legal rights concerning water resources, while it assigned rights of use to the end users. It was presumed that privatization of land and state control over water resources would create incentives that would lead to greater productivity than other forms of property arrangements. Consequently, the informal water associations, which had guaranteed the control of access to and extraction of common water resources, gradually lost their legitimacy in the structure of water governance. 
The highly centralized policy making and the nested structure of the competent public administrations have focused almost exclusively on meeting the water demands of Sanandaj City and the farmland of the neighbouring provinces, rather than on a sustainable social-ecological system, by establishing conditions for thorough environmental assessment. Water users in all communities, whether in the study area or elsewhere, are viewed as a single homogeneous group that behaves uniformly, and are consequently not recognized as distinct populations with different characteristics. This approach results in a divergence between individual, state-based and collective governance of the common resources, which blocks individuals from getting involved in decision making and implementation.

The executive administrations, ranging from the county level to the national level and consisting of segregated functional pillars among which roles and responsibilities are not clearly divided, have been ineffective in establishing well-defined rules concerning property rights, the limiting of access and extraction, the exclusion of unauthorized users, or the provision of sufficient monetary resources for microscale monitoring. The relationship between the state and the users in the communities has materialized in new administrative bodies, although a slight overlap of competences between the communities and these administrative bodies has remained. When water as a well-defined communal property lost its characteristics of excludability and rivalry, it was first turned into state property. Then, due to the inefficiency of the state regarding necessary monitoring and control, private users were released from direct monitoring by the traditional associations, and each user obtained a degree of authority and relative autonomy and a substantial level of independence. Under such a regime, it became difficult for the executive administrations of the Regional Water Authority to prevent unauthorized use of groundwater and surface water bodies, which are objects of rivalry among powerful public actors. Although this was not the intention, the resulting system was close to an open access regime with respect to the common-pool resource of water, and groundwater in particular.

We find that the lack of profound understanding of the social and ecological impact of the shift in ownership of water resources has fundamentally altered several characteristics of the water system in the study area, including the typology of property rights and the size of the user group, which evolved from a well-defined group of end users in a few villages into a dispersed crowd of individual users with respect to groundwater, or an entire county or even multiple provinces with respect to surface water. Also, the nature of the user groups has changed from local users to outsiders from the neighbouring provinces, and the level at which actual management is performed has moved from a human scale, based on locally crafted institutions, face to face and with informal interaction and rules, socially enforced by the users themselves, to large-scale practices and formal top-down decision making, with rules and regulations imposed by technical experts in central bureaucracies and enforced by administrations which are not themselves water users.

Eventually, in Iran, turning communal water resources into a national competence has strengthened the political power of public and private actors and has significantly degraded the benefits attached to the folk co-management system and the social cohesion of local associations. Likewise, the shift has relaxed user attitudes to the preservation of water under communal ownership regimes and has reinforced the myth of abundance. This development has even fuelled population growth, urbanization and the unbalanced distribution of water supply, in a vicious circle of growing demand for water, leading to a tragedy of the commons. Thus, from an international perspective, any change in the ownership of natural resources requires careful assessment of the consequences, since it will probably alter the socioenvironmental conditions of the target area.

\section{Conclusion}

In this study, we have examined two successive and contrasting ownership regimes in the field of water resources in the study area of Sanandaj County. We conclude that the case of Sanandaj County's folk water management system contrasts positively with other, often unsuccessful cases of communal 
property described in the literature, due to (1) the legitimacy of the communal rights that were defined within the applicable legal framework, (2) the presence of collective full property rights, and (3) the appropriate scale of monitoring and sanctioning modalities. Even though the folk water management might have failed to meet the recent increase in water demand, the results of the technocratic elements of the Iranian water management structure, such as dam construction, are incapable of providing accurate measurements and low-cost monitoring, or of obtaining information about extraction rates for groundwater, and have deprived much of the community in the study area of access to surface water. Finally, we conclude that the effectiveness of a communal ownership regime in sustaining common property is affected by the type of management structure. State ownership of water resources and services in the study area has proven to be less effective and efficient than the communal ownership regime.

However, any policy recommendation to enhance adaptive capacity for gaining water security, both in the study area and at the national level, needs to also consider the roles of food, energy and climate, which are all linked to the increasing demand for water. As an alternative to controlling the ecosystem, the government's intervention in water management could limit itself to defining the national and longterm strategies for supporting local communities in progressing towards adaptive co-management of water resources. Such strategies could then be region-specific, focused on enhancing biodiversity and promoting local development, instead of one-size-fits-all solutions such as providing guidelines for virtual water trading among local communities, or focusing on renewable energy provisions instead of implementing physical infrastructure for energy production. Also, non-governmental actors could be involved in establishing and implementing a regulatory framework for public decision makers and private users. Incidentally, a precise demarcation of groups of beneficiaries and a locally rooted regulatory framework, which is in line with the collective use of common resources, could help in moving beyond widespread and simple solutions and allow social norms to evolve. A good reason for this is that adaptive management and soft measures, such as appropriate regulations for sanctioning and monitoring of water consumption, often cost less than technical management.

A fundamental response to such goals requires revaluing domestic social-ecological knowledge, and needs to reinstate the abandoned local associations for governing water resources under a communal ownership regime, which for centuries were dominant in water management practice and well adapted to the goals of sustainable use of common water resources in arid regions. If the local expertise available in community-based governance has not been ignored in contemporary approaches to water management, it could have contributed to identifying problems and developing community-based solutions in the study area. Their knowledge would have supported the establishment of a more sustainable water governance system and helped avoid a tragedy of the commons. For instance, newly launched local associations could organize themselves to rehabilitate the abandoned qanats, implement small-scale infrastructure for aquifer recharge, promote rainwater harvesting from built-up surfaces, monitor the cultivation patterns of farmers under the general guidelines of the government, or facilitate the adoption of new technologies in local communities. In that sense, understanding the social mechanisms behind folk co-management could be a starting point towards compliance with environmental regulations and excluding unauthorized users.

These findings contribute to the important theoretical debate about the extent to which national blueprint approaches to water management can warrant sufficient levels of availability and sustainability, and how they can be combined with more local-based approaches from diverse disciplinary perspectives. Further empirical and theoretical work is needed to demonstrate how institutional, cultural and biophysical contexts affect social learning and can change social norms and develop collective actions, all of which are required for the development of the public policies needed to reduce the uncertainties and complexities of the water management system.

\section{References}


Agrawal, A. (2003). Sustainable governance of common-pool resources: Context, methods, and politics. Annual Review of Anthropology, 32(1), 243-262. https://doi.org/10.1146/annurev. anthro.32.061002.093112

Ahmadi, H., Samani, A. N., \& Malekian, A. (2010). The qanat: A living history in Iran. In G. Schneier-Madanes \& M. F. Courel (Eds.), Water and sustainability in arid regions (pp. 125-138). Springer.

Aligica, P. D., Ostrom, E., Ostrom, V., Tiebout, C. M., \& Warren, R. (2014). Elinor Ostrom and the Bloomington School of Political Economy: Polycentricity in public administration and political science (Vol. 1). Lexington Books.

Amin, M. I., Qazi, R., \& Downing, T. E. (1983). Efficiency of infiltration galleries as a source of water in arid lands. Water International, 8(4), 158-165. https://doi.org/10.1080/02508068308686034

Balali, M. R. (2009). Towards reflexive land and water management in Iran: Linking technology, governance and culture. Wageningen University. PhD thesis.

Barnett, H. J., \& Morse, C. (2013). Scarcity and growth: The economics of natural resource availability. Routledge.

Berkes, F. (2005). Commons theory for marine resource management in a complex world. Senri Ethnological Studies, 67, 13-31. https://doi.org/10.15021/00002658

Berkes, F., Colding, J., \& Folke, C. (2000). Rediscovery of traditional ecological knowledge as adaptive management. Ecological Applications, 10(5), 1251-1262.

Berkes, F., Colding, J., \& Folke, C. (Eds.). (2008). Navigating social-ecological systems: Building resilience for complexity and change. Cambridge University Press.

Boustani, F. (2008). Sustainable water utilization in arid region of Iran by Qanats. Proceeding of World Academy of Science, Engineering and Technology, 33, 213-216.

Bromley, D. W. (1991). Testing for common versus private property: Comment. Journal of Environmental Economics and Management, 21(1), 92-96. 0095-0696/91. https://doi.org/10. 1016/0095-0696(91)90007-6

Cai, X. (2008). Water stress, water transfer and social equity in Northern China: Implications for policy reforms. Journal of Environmental Management, 87(1), 14-25. https://doi.org/10.1016/j. jenvman.2006.12.046

Cinner, J. E., \& Aswani, S. (2007). Integrating customary management into marine conservation. Biological Conservation, 140(3-4), 201-216. https://doi.org/10.1016/j.biocon.2007.08.008

Clark, C. W. (1980). Restricted access to common-property fishery resources: A game-theoretic analysis. In P. T. Liu (Ed.), Dynamic optimization and mathematical economics (pp. 117-132). Springer.

Comair, F. (2007). Water sector in Lebanon: An operational framework for undertaking legislative and institutional reforms. United Nations Economic and Social Commission for Western Asia, 46.

Dietz, T., Ostrom, E., \& Stern, P. C. (2003). The struggle to govern the commons. Science, 302 (5652), 1907-1912. https://doi.org/10.1126/science.1091015

Energy Ministry. (2015). Water shortage warning to 37 million Iranians / 11 metropolises entered water stress. https://www.mehrnews.com/news/2269140/

Ervin, J. (2003). Rapid assessment of protected area management effectiveness in four countries. BioScience, 53(9), 833-841. https://doi.org/10.1641/0006-3568(2003)053[0833:RAOPAM]2.0.CO;2

Feeny, D., Berkes, F., McCay, B. J., \& Acheson, J. M. (1990). The tragedy of the commons: Twentytwo years later. Human Ecology, 18(1), 1-19. https://doi.org/10.1007/BF00889070

Flaherty, B., Pacheco-Vega, R., \& Isaac-Renton, J. (2011). Moving forward in Canada-United States transboundary water management: An analysis of historical and emerging concerns. Water International, 36(7), 924-936. https://doi.org/10.1080/02508060.2011.628796

Foltz, R. C. (2002). Iran's water crisis: Cultural, political, and ethical dimensions. Journal of Agricultural \& Environmental Ethics, 15(4), 357-380. https://doi.org/10.1023/ A:1021268621490 
Gadgil, M., Berkes, F., \& Folke, C. (1993). Indigenous knowledge for biodiversity conservation. Ambio, 22(2/3), 151156.

Habibi, J. (2017). Report of Energy Ministry. National Conference of Water Resources. The National Company of Iranian Water Resources Management.

Hardin, G. (1968). The tragedy of the commons. Science, 162(3859), 1243-48. https://doi.org/10.

$1126 /$ science.162.3859.1243

Hardin, G. (1978). Political requirements for preserving our common heritage. In H. P. Brokaw (Ed.), Wildlife and America (pp. 310-317). Council on Environmental Quality.

Heynen, N., \& Robbins, P. (2005). The neoliberalization of nature: Governance, privatization, enclosure and valuation. Capitalism Nature Socialism, 16(1), 5-8. https://doi.org/10.1080/ 1045575052000335339

Huang, Q., Rozelle, S., Wang, J., \& Huang, J. (2009). Water management institutional reform: A representative look at northern China. Agricultural Water Management, 96(2), 215-225. https:// doi.org/10.1016/j.agwat.2008.08.002

Jie, J. S. F. Z. (2011). Institutional reform of water resources management in China. China Population, Resources and Environment, 10.

Jomehpour, M. (2009). Qanat irrigation systems as important and ingenious agricultural heritage: Case study of the qanats of Kashan, Iran. International Journal of Environmental Studies, 66(3), 297-315.

https://doi.org/10.1080/00207230902752629

Karimi, N., \& Boussauw, K. (2018). Sanandaj, Iran. Cities, 72, 261-273. https://doi.org/http://dx. doi.org/10.1016/j.cities.2017.09.004

Kordovani, P. (2015). Conference of water resources and agriculture in drought areas. Tehran University.

Larijani, K. M. (2005). Iran's water crisis: Inducers, challenges and counter-measures. 45th Congress of the European Regional Science Association: "Land Use and Water Management in a Sustainable Network Society", 23-27 August 2005, Amsterdam, The Netherlands. http://hdl. handle.net/10419/117725

Li, W. J., Ali, S. H., \& Zhang, Q. (2007). Property rights and grassland degradation: A study of the Xilingol Pasture, Inner Mongolia, China. Journal of Environmental Management, 85 (2), 461-470.

https://doi.org/10.1016/j.jenvman.2006.10.010

Lovejoy, T. E. (2006). Protected areas: A prism for a changing world. Trends in Ecology \& Evolution, 21(6), 329-333. https://doi.org/10.1016/j.tree.2006.04.005

Madani, K. (2014). Water management in Iran: What is causing the looming crisis? Journal of Environmental Studies and Sciences, 4(4), 315-328. https://doi.org/10.1007/s13412-014- 0182-z

Madani, K., \& Dinar, A. (2010). Non-cooperative institutions for sustainable management of common pool resources. Water Science and Policy Center, University of California, Riverside. https://doi.org/10.1029/2011WR010849s

Marjanizadeh, S., de Fraiture, C., \& Loiskandl, W. (2010). Food and water scenarios for the Karkheh River Basin, Iran. Water International, 35(4), 409-424. https://doi.org/10.1080/ 02508060.2010.506263

Moqimi, S., Baqeri, A., \& Abilhasani, L. (2016). Application of learning loops for analyzing the effectiveness of the law of determining unauthorized wells. National Conference of Water Management, Sanandaj, 104(2), 77-90. In Persian.

National Central Bank. (2014). International water indicators survey and the prospect of a global water crisis on the horizon of 2050. In Persian.

Ohmagari, K., \& Berkes, F. (1997). Transmission of indigenous knowledge and bush skills among the Western James Bay Cree women of subarctic Canada. Human Ecology, 25(2), 197-222. https://doi.org/10.1023/A:1021922105740

Ostrom, E. (2000). Collective action and the evolution of social norms. Journal of Economic Perspectives, 14(3), 137158. https://doi.org/10.1257/jep.14.3.137 
Ostrom, E. (2002). Common-pool resources and institutions: Toward a revised theory. Handbook of Agricultural Economics, 2, 1315-1339.

Ostrom, E. (2008). The challenge of common-pool resources. Environment: Science and Policy for Sustainable Development, 50(4), 8-21.

Ostrom, E., \& Hess, C. (2007). Private and common property rights. Encyclopedia of Law \& Economics. Edward Elgar. http://papers.ssrn.com/sol3/papers.cfm?abstract_id=1304699

Ostrom, E., \& Schlager, E. (1996). The formation of property rights. In S. S. Hanna, C. Folke, \& K. G. Maler (Eds.), Rights to nature: Ecological, economic, cultural and political principles of institutions for the environment (pp. 127137). Island Press.

Ostrom, E. E., Dietz, T. E., Dolšak, N. E., Stern, P. C., Stonich, S. E., \& Weber, E. U. (2002). The drama of the commons. National Academies Press. https://doi.org/10.17226/10287

Pahl-Wostl, C., Isendahl, N., Möllenkamp, S., Brugnach, M., Jeffrey, P., Medema, W., \& de Vries, T. T. (2006). Paradigms in water management. Report of the NeWater Project: New approaches to adaptive management under uncertainty. NeWater.

Papeli Yazdi, H. (2016). Fedosi University of Mashad, Conference on national water resources. In Persian.

Punjabi, B., \& Johnson, C. A. (2019). The politics of rural-urban water conflict in India: Untapping the power of institutional reform. World Development, 120, 182-192. https://doi.org/10.1016/j. worlddev.2018.03.021

Raymond, L. S., \& Raymond, L. (2003). Private rights in public resources: Equity and property allocation in marketbased environmental policy. Resources for the Future.

Sakurai, T., Rayamajhi, S., Pokharel, R. K., \& Otsuka, K. (2004). Efficiency of timber production in community and private forestry in Nepal. Environment and Development Economics, 9(4), 539- 561.

https://doi.org/10.1017/S1355770X04001457

Schlager, E., \& Ostrom, E. (1992). Property-rights regimes and natural resources: A conceptual analysis. Land Economics, 68(3), 249-262. https://doi.org/10.2307/3146375

Siddiki, S., Heikkila, T., Weible, C. M., Pacheco-Vega, R., Carter, D., Curley, C., Deslatte, A., \& Bennett, A. (2019). Institutional analysis with the institutional grammar. Policy Studies Journal. https://doi.org/10.1111/psj.12361

Statistical Centre of Iran. (2016). General population and housing census. Statistical Centre of Iran. In Persian.

Tabari, H., Somee, B. S., \& Zadeh, M. R. (2011). Testing for long-term trends in climatic variables in Iran. Atmospheric Research, 100(1), 132-140. https://doi.org/http://dx.doi.org/10.1016/j. atmosres.2011.01.005

Tucker, C. (2010). Private goods and common property: Pottery production in a Honduran Lenca community. Human Organization, 69(1), 43-53. https://doi.org/10.17730/humo.69.1. 8581463255p28526

Williamson, O. E. (2000). The new institutional economics: Taking stock, looking ahead. Journal of Economic Literature, 38(3), 595-613. https://doi.org/10.1257/jel.38.3.595

Wulff, H. E. (1968). The qanats of Iran. Scientific American, 218(4), 94-107. https://doi.org/10. 1038/scientificamerican0468-94 23 